\title{
The Influence of Policy Risk on Swiss Wind Power Investment
}

\author{
Anna Broughel and Rolf Wüstenhagen
}

\begin{abstract}
Contents

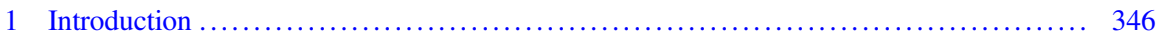

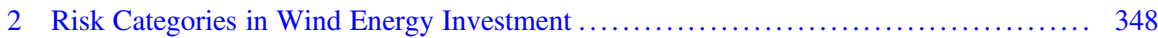

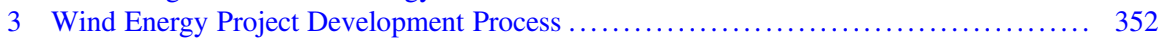

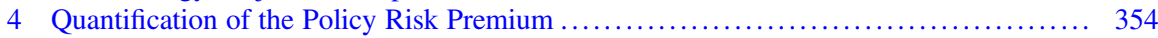

4.1 Methodological Approach .......................................... 354

4.2 Results: The Price of Policy Risk ................................. 360

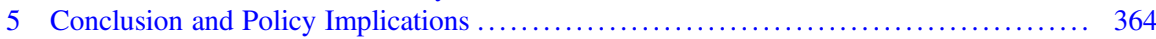

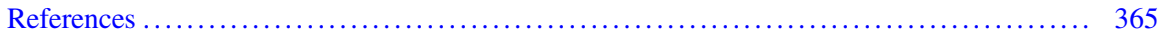

\begin{abstract}
Wind energy is one of the most affordable and fastest-growing sources of electricity worldwide. As a large share of wind power generation occurs in the winter season, it could make an important contribution to seasonal diversification of domestic electricity supply. However, the development of wind energy projects in Switzerland has been characterized by long and complex administrative processes, with the planning phase taking up to a decade, more than twice as long as the European average. The objective of this chapter is to quantify the risk premium that lengthy permitting processes imply for wind energy investors in Switzerland and to suggest ways to reduce policy risk. The data have been gathered through 22 confidential interviews with project developers and several cantonal permitting agencies as well as a review of federal and cantonal regulatory documents. Furthermore, a discounted cash flow model was built to compare the profitability indicators (IRR, NPV) and the levelized cost of electricity (LCOE) of a reference case to scenarios with various risks - for example, delays in the permitting process, downsizing the
\end{abstract}

This chapter is a significantly revised and updated version of a manuscript that has previously been included in the final report of a project which has received funding from the Swiss Federal Office of Energy (see Wüstenhagen et al. 2017, pp. 10-35). The authors bear the entire responsibility for the content of this chapter and for the conclusions drawn therefrom.

\footnotetext{
A. Broughel · R. Wüstenhagen $(\bowtie)$

University of St. Gallen, Chair for Management of Renewable Energies, St. Gallen, Switzerland e-mail: anna.broughel@tetratech.com; rolf.wuestenhagen@unisg.ch
} 
project, or changes in the regulatory environment such as phasing out feed-in tariffs. The model shows that the highest profitability risks are related to the availability of a feed-in tariff, but other changes in the permitting process can also have a critical impact on the project's bottom line. The findings illustrate a significant policy risk premium in the pre-construction stage faced by wind energy project developers in Switzerland.

\section{Introduction}

The Swiss Energy Strategy 2050 (ES2050), which established ambitious energy efficiency and renewable electricity production targets and a ban for new nuclear power plants, ${ }^{1}$ was accepted by $58.2 \%$ of the voters in a May 2017 referendum. $^{2}$ As a consequence, wind energy projects, together with other renewable energy sources, were granted the status of "national interest", thus leveling the importance of renewable power generation with other national interests, such as landscape protection. ${ }^{3}$ Another important implication was that no new feed-in-tariff payments ("kostendeckende Einspeisevergütung KEV") would be earmarked for renewable energy after the end of 2022. Since January 2018, the previous KEV system has been changed towards a system of feed-in remuneration with direct marketing. ${ }^{4}$

ES2050 recommends a target of $11,400 \mathrm{GWh}$ of new renewables (without hydropower) in $2035^{5}$ and it is expected that wind energy will play an important part in fulfilling this goal. By the end of 2018, there were $75 \mathrm{MW}$ of wind energy capacity installed in the country, producing roughly 122 GWh of electricity, which corresponds to the electricity consumption of 35,000 Swiss households. ${ }^{6}$ These numbers suggest that in order to meet the federal production targets, wind power needs to see significant growth in the coming years. Administrative and regulatory issues $^{7}$ are among the major barriers to the development of renewable energy projects in Switzerland and internationally. ${ }^{8}$ Leading Swiss governmental and industry stakeholders have identified the duration of administrative processes as an area of

\footnotetext{
${ }^{1}$ Swiss Federal Office of Energy (2016a).

${ }^{2}$ Federal Chancellery (2017).

${ }^{3}$ Energy Act (Energiegesetz, SR 730.0), Art. 12.

${ }^{4}$ For the sake of brevity, we use the term "KEV" in this chapter to refer to Swiss feed-in tariffs, including the system of feed-in remuneration with direct marketing introduced in 2018.

${ }^{5}$ Energy Act (Energiegesetz).

${ }^{6}$ Suisse Eole (2019).

${ }^{7}$ The words "administrative", "planning", "permitting", and "regulatory" costs are used interchangeably to refer to the costs borne by the project developer before the construction of wind turbines takes place.

${ }^{8}$ Battaglini et al. (2012); Burkhardt et al. (2015); Dong and Wiser (2013); Ceña et al. (2010).
} 
concern: it can take more than 10 years to obtain all the necessary permits to construct a large wind energy project. ${ }^{9}$ By comparison, the average pre-construction lead times are 4.5 years in Europe, with a considerable variation by country. ${ }^{10}$ The long duration and complexity of the permitting process result in reduced attractiveness of the Swiss market for foreign and domestic investors, who prefer shorter administrative procedures. ${ }^{11}$ This preference is financially sound: administrative costs are 'sunk' and increase the levelized cost of electricity (LCOE), thus directly impacting project profitability.

There are several types of costs that are connected to permitting procedures. The first type is easily quantifiable- these are direct monetary expenses, such as permitting fees or expenses on environmental impact assessment (EIA) and ecological compensation. We argue that administrative delays incur additional indirect costs, which have a detrimental and significant effect on the financial attractiveness of a wind project due to opportunity cost of capital and foregone profits. Moreover, delays give rise to regulatory and policy risk and uncertainty with respect to the federal support scheme and possible changes in environmental and spatial planning laws. Taken all together, we posit that direct and indirect costs of permitting and associated risks constitute a significant barrier for wind energy project development in Switzerland.

The aim of this chapter is to quantify the cost of regulatory and policy risks (the "risk premium") faced by investors in Swiss wind energy projects. The research focuses on the question: How can the policy risk premium for planning and permitting of wind energy projects be quantified and reduced? To answer this question, we describe wind energy project permitting procedures, summarize empirical data on their costs and duration, and analyze the impacts that regulatory risks have on LCOE under different scenarios.

Our analysis is informed by a review of publicly available documents and interviews with federal and cantonal authorities. The aim of the interviews was to cross-check information obtained from public documents and identify the most important bottlenecks. Industry-related data were gathered through 22 confidential interviews with wind energy project developers in German and French-speaking parts of Switzerland.

The results have significant policy relevance. To invest in renewable energy, project developers have to recover the cost of electricity production ("hard cost") as well as the associated risk premium ("soft cost"). While technological and market risks can be reduced through careful due diligence by the project developers, political and regulatory risks are harder to manage. ${ }^{12}$ Quantifying the risk premium induced by the administrative process will allow a more precise calculation of adequate levels of public support, which will help policymakers balance the multiple

\footnotetext{
${ }^{9}$ Guy-Ecabert and Meyer (2016); Suisse Eole (2016).

${ }^{10}$ Ceña et al. (2010).

${ }^{11}$ De Jager and Rathmann (2008); Lüthi and Wüstenhagen (2012).

${ }^{12}$ Noothout et al. (2016); Bürer and Wüstenhagen (2008).
} 
objectives of providing investor confidence, securing low-carbon electricity supply, protecting local landscapes and the environment, and maintaining affordable electricity prices.

The rest of this chapter has the following structure. First, we classify the risk categories faced by wind project developers and visualize the complexity of the administrative process for building large wind energy projects in Switzerland. Then, we quantify the policy risk premium based on the calculation of project profitability and LCOE under eight different scenarios. Finally, policy implications and recommendations for risk reduction are derived, informed by the model results and interview insights.

\section{Risk Categories in Wind Energy Investment}

This section investigates ten risks from the wind energy project developer's perspective, adapted from Noothout et al. ${ }^{13}$ Careful consideration and weighting of wind energy project risks are paramount for successful project completion. While some risks are regulatory in nature and can be somewhat mitigated, a number of other factors need to be accepted "as is", exposing the project developer to cumulative project risk.

Policy design risk, policy change risk and administrative risk are the most relevant for our research, since they cannot be easily managed by the project developer. Policy design risk is connected to opportunities and threats arising from how the policy instrument is designed by the authorities, including duration and size of support and existence of a support cap. Since 2009, Swiss authorities have been offering feed-in-tariffs (KEV), a fixed remuneration paid for electricity produced from renewable sources for the duration of 20 years. ${ }^{14}$ The KEV ensures that electricity generators receive compensation for the green power they produce and shields the project cash flows from the price volatility of the electric power markets. Moreover, wind projects that are ready to be built enjoy preferential treatment in the KEV system. ${ }^{15}$

Even though KEV offers an attractive and stable revenue stream, there are several challenges with the current implementation of this policy instrument in Switzerland, which translate into considerable risk for developers. The first challenge is the risk of not receiving KEV (considered by Scenarios VI-VIII in section 4.2). In fact, in the third quarter of 2019, only 40 wind turbines with an installed capacity of 62 MW benefited from KEV support. ${ }^{16}$ Another 438 wind projects with a capacity of 1014 MW were approved for KEV support should they be built, and an additional

\footnotetext{
${ }^{13}$ Noothout et al. (2016).

${ }^{14}$ Swiss Federal Office of Energy (2016b).

${ }^{15}$ Swiss Federal Office of Energy (2016a).

${ }^{16}$ Pronovo (2019a).
} 
356 planned wind energy projects with a nominal capacity of $843 \mathrm{MW}$ were on the KEV waiting list, unlikely to get approval before the 2022 expiration of the feed-in tariff system. ${ }^{17}$ Relieving this bottleneck could contribute significantly to achieving Switzerland's renewable energy goals. If half of the currently planned projects were implemented by 2035 , this would lead to an expected annual power generation of $1637 \mathrm{GWh}$ or $14 \%$ of the ES2050 target. ${ }^{18}$

Policy change risk: The second challenge is uncertainty about the subsequent support scheme after the KEV system is discontinued. Article 38 of the revised Energy Act specifies a sunset clause that phases out feed-in tariffs after 2022, suggesting that the majority of wind projects on the waiting list are unlikely to receive KEV support. ${ }^{19}$ The design of a possible public support scheme after 2022 is currently unknown, which is a source of considerable uncertainty for project developers.

Administrative risks can be recognized as a significant hurdle to wind power development in Switzerland, as they have been internationally. ${ }^{20}$ The risk stems from complex permitting procedures (described in detail in Sect. 3), variations of procedures by canton, changing requirements for environmental impact assessment (EIA), long administrative lead times, multiple opportunities for objections on the cantonal and municipal level, and the high number of authorities involved. The administrative risks bring about additional costs (e.g., new environmental impact studies), cause project delays (e.g., pending court cases), and introduce uncertainty (e.g., regarding a project's chances of receiving financing).

Social acceptance risk: Another important risk in the planning phase is connected to social acceptance, which includes acceptance by the markets, local communities, and society in general. ${ }^{21}$ Note that social acceptance is closely intertwined with administrative risks, since projects with significant opposition from the local population or the NGOs are often delayed and are less likely to receive the necessary permits. Generally, Swiss public opinion polls show high approval ratings of wind energy: a favorable public opinion has been a defining trend in Switzerland for more than a decade. ${ }^{22}$ Even though intense political campaigns ahead of voting can lead to opinion swings, ${ }^{23}$ local voters accepted 19 out of 22 specific wind energy projects in the past 7 years. ${ }^{24}$

Public support for wind energy does not mean that all stakeholders are on board with wind energy development. Often, there is a highly organized and influential

\footnotetext{
${ }^{17}$ Pronovo (2019b).

${ }^{18}$ Own calculation based on data from Pronovo (2019a).

${ }^{19}$ Swiss Federal Office of Energy (2016a).

${ }^{20}$ Ceña et al. (2010); Lüthi and Prässler (2011).

${ }^{21}$ Wüstenhagen et al. (2007).

${ }^{22}$ Geissmann (2015); Ebers and Wüstenhagen (2016); Ebers Broughel and Hampl (2018); Tabi and Wüstenhagen (2015); Tamedia (2017).

${ }^{23}$ Rinscheid and Wüstenhagen (2018); see also Rinscheid and Udris (2021).

${ }^{24}$ Perret (2019).
} 
opposition, which presents a variety of arguments against wind power development. These concerns are usually related to impacts of wind turbines on different aspects of local life: environmental (impacts on local flora and fauna, landscape change), emotional (place attachment), technological (contestation of wind technology), health-related (impact of noise, flicker), and economic (unfavorable perceived cost-benefit ratio of wind power development). In the academic literature, the issues of social acceptance are discussed in the context of environmental equity and fairness of renewable energy generation. ${ }^{25}$ The project developers usually search collaboration and compromise with the opposition, which might involve commissioning of additional studies, introduction of ecological mitigation measures, changing the location of turbines, reducing the number of turbines, and switching off turbines when birds and bats are most likely to be impacted. Our estimations show that these factors may have significant financial consequences for the project developer. Social acceptance risks can be addressed through a careful stakeholder management strategy, but they cannot be fully avoided.

A wind project might receive dozens of objections, most of which are settled out of court. When a compromise cannot be found, the courts are likely to get involved. The task of the court is to weigh the conflicting interests: for example, environmental protection versus domestic energy supply. ${ }^{26}$ Court cases have considerable impacts on the project's cash flow. Court deliberations lead to direct monetary expenses, such as remuneration for lawyers, expenses for commissioning new studies and project managers' work hours. The objections often lead to considerable delays, putting the project on hold for the duration of the court deliberations. Municipal courts are likely to hear a case in about 6 months, while the cantonal courts might require a year to reach a decision. A federal court is likely to need several years to announce their verdict. Multiple court cases might delay the project to the extent that it can no longer be realized.

Grid access risk: The project developer greatly depends on the availability of a grid connection; therefore, this is among the first points to be clarified in the initial project stages. If there are no suitable connection options available, the developer usually abandons the project idea because building new electric infrastructure can be prohibitively expensive. Generally, project developers tend to seek a close collaboration with the local grid operators.

Financing risk: Due to the stability of the Swiss financial system and currently very low interest rates, the developers are able to finance wind projects with relatively low cost of capital. Yet, financing of the existing wind projects in Switzerland was greatly facilitated by receiving a KEV, thus connecting the financing risk of project development with federal policy-making. The interviewees have reported that without the KEV, their projects are unlikely to obtain financing, as they would be exposed to volatile electricity prices, making it harder to present a clear

\footnotetext{
${ }^{25}$ E.g., see Wolsink (2007); Wüstenhagen et al. (2007).

${ }^{26}$ Plüss (2017).
} 
investment case. In the absence of KEV, a long-term power purchasing agreement (PPA) might make the wind project financially attractive, if it covers LCOE.

Technology risk relates to the level of maturity of wind energy technology. Even though wind turbines are a novelty in many regions, wind power is a mature technology. The developer cannot influence the maturity of the best available technology, but a project can be designed to use the most appropriate technological solution, given local wind conditions, altitude, and environmental impacts. In recent years, technological progress has permitted the construction of increasingly larger turbines for increasingly lower cost, which tremendously improved the cost efficiency of wind energy per MW of installed capacity. One of the challenges of rapid technological development is that in the case of serious delays, by the time the project obtains all the necessary permits, the technology specified in the permitting documentation may be outdated or even no longer available. In this case, some permitting steps need to be repeated. ${ }^{27}$ On the other hand, some project delays can also be an advantage, as they allow the developer to gather further information about the site and employ more efficient wind turbines as they become available on the market.

Management risk is related to the overall experience level of the project developer to successfully plan, commission, operate, and decommission or repower the wind project. Our interviews identified a significant learning-by-doing effect, as project developers learn about the complex permitting procedures. An experienced project team has the potential to reduce management risk.

To complete the picture, project developers are subject to market design and country risks, which equally apply to all electricity producers. These two risks pertain to such factors as: political stability, level of corruption, economic development, design and functioning of the electricity market, the legal system, and exchange rate fluctuations. The Swiss electricity market is partially liberalized, with the second stage of liberalization depending on an electricity trading agreement with the EU. The electricity market is dominated by public utilities, which makes the entrance of smaller players more challenging. ${ }^{28}$ This stands in contrast with many private wind energy developers who are active in such countries as the US, Germany, the UK, or Sweden. ${ }^{29}$ At the same time, Switzerland is a rather small market, which makes large-scale renewable energy developments challenging. As a result, many Swiss developers have built or acquired wind projects abroad. ${ }^{30}$

\footnotetext{
${ }^{27}$ One standard practice is to use approximate turbine characteristics in the beginning of the permitting process and avoid specifying the turbine model for as long as possible.

${ }^{28}$ Ebers Broughel et al. (2019).

${ }^{29}$ E.g., Bergek et al. (2013).

${ }^{30}$ Blondiau and Reuter (2019).
} 


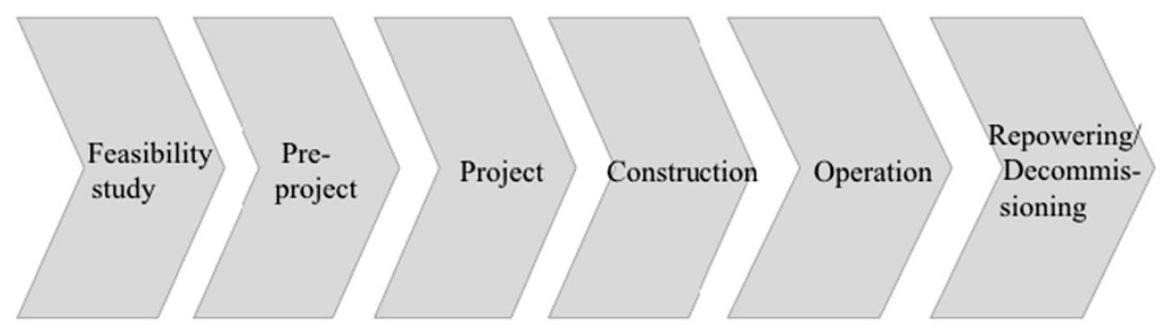

Fig. 1 Wind power project development process

\section{Wind Energy Project Development Process}

Wind energy projects are subject to a rigorous technical, financial, ecological, and geological evaluation, with the involvement of multiple stakeholders. ${ }^{31}$ Fig. 1 shows the project development process of a wind park, consisting of six distinct steps: feasibility study, pre-project, main project, construction, operation, and repowering or decommissioning.

In Switzerland, the pre-construction stage (first 3 project steps) can last between 6 and 7 years without objections and stretch up to 15 or more years in case the project faces regulatory hurdles or opposition. In this stage, the project developer expects to spend 5-10\% of the total budget on planning and permitting activities, which might range from several hundred thousand Swiss francs (in case no EIA is needed) to 3-6 million CHF. It must be noted that exact development costs are difficult to predict, since the requirements for implementing wind projects have increased tremendously, putting an upward pressure on pre-construction budgets. Moreover, pre-construction costs do not linearly increase with project size, as they are made up of fixed costs (independent of project size) and variable costs (dependent on project size, but also on location, the situation in the community, objections, cantonal planning decisions, etc.). Thus, larger projects tend to expose project developers to higher pre-construction risks (and expenses) because they require more extensive EIAs, more permits for wind measurement towers, complex technical planning, and coordination among multiple jurisdictions and landowners. On the other hand, in case of larger projects, the development costs are spread over a larger installed capacity, thus reducing cost per megawatt. To mitigate pre-construction risks, project developers were observed to form partnerships for the development of larger projects (cost sharing) or to develop a small lighthouse project first (costminimizing). In both cases, potential project failure would result in smaller monetary losses.

Exact pre-construction steps somewhat vary by developer, prior experience, and the jurisdiction. The initial "exploratory" stage of the project results in the feasibility study, which usually takes 1-2 years to complete. The study includes rough wind

\footnotetext{
${ }^{31}$ Twele and Liersch (2011).
} 
potential evaluations, an initial consideration of environmental impacts and accessibility options, a preliminary geological assessment of the grounds, an evaluation of suitable wind turbines, and an initial financial appraisal. In this phase, the approximate project location and the number of turbines are proposed. This is also the time for the initial contact with local stakeholders. The authorities are contacted for information on permits and zoning requirements. Consent of the land owner(s) is of paramount importance, and it is usually secured through a contract. Interconnection options are discussed with the grid operator. Most project developers have applied for KEV by submitting a free-of-charge online application to the relevant agency, Pronovo (formerly Stiftung KEV). This is a rather fast and straightforward procedure. If the KEV approval is granted, the project developer has to notify the authorities of the project status every 2 years.

At the pre-project stage, all of the previously mentioned points get a deeper and more detailed assessment. The project developer obtains reliable wind speed data, by installing a wind measurement tower to monitor wind speeds, usually for 1 year. A more detailed pre-project file is submitted to the municipal and cantonal authorities for evaluation, so that the project can be integrated in the zoning plans.

The main project builds upon the outcome of the pre-project and includes a number of detailed studies, which are made to satisfy the building permit application and requirements of the Federal Inspectorate for Heavy Current Installations. ${ }^{32}$ This stage can take several years and often stretches out longer due to delays. The main project file usually includes the following components: a detailed wind speed evaluation, a road access assessment, an interconnection study, contracts with the landowner, a technical plan, a business plan, and a full EIA with suggested measures of ecological compensation. The EIA, compulsory for projects over $5 \mathrm{MW}$, is an especially important part of the project plan, as it assesses the project's influence on flora, fauna, landscape, and noise exposure. ${ }^{33}$ The EIA often represents a stumbling stone for project developers. Authorities, courts, and external stakeholders can require additional environmental studies, which range in cost between 30 and $300 \mathrm{kCHF}$ each and take months (and sometimes several years) to complete. Generally, the authorities recommend clustering wind power developments, thus avoiding locations with high natural value. ${ }^{34}$ Finally, the municipality decides whether to grant the project a construction permit, which takes several years with a possibility of a referendum. After the project receives all necessary permits, the construction phase begins. In order to install wind turbines, a number of infrastructural improvements (clearing forests, building roads) are often needed.

The next phase is the operational phase, which is the longest phase of the project cycle. It can last 20 years or more, and this is actually the first time when the project is generating revenues. During this time, the project developer might also implement ecological compensation measures to mitigate project impacts on flora, fauna and

\footnotetext{
${ }^{32}$ https://www.esti.admin.ch/en/esti-homepage

${ }^{33}$ Federal Council (2016).

${ }^{34}$ Federal Office for Spatial Development (2017).
} 
local residents. After the end of the operational phase, the project can be either decommissioned or repowered with new turbines. ${ }^{35}$

While the six steps of the project development process seem straightforward, the picture becomes more complicated when the complexities of the administrative process are taken into account. In Fig. 2, we mapped out the permitting steps and the stakeholders involved, with arrows denoting the most significant interdependencies.

As evident from this visualization, the project developer has to obtain permits or decisions from a number of federal agencies, including aviation authorities, military authorities, the Federal Inspectorate for Heavy Current Installations, the Federal Office for the Environment, to name a few. To simplify this permitting process, the Federal Office of Energy has set up a one-stop-shop called "guichet unique",36 to allow project developers to have a single point of contact with relevant federal authorities, instead of having to coordinate among multiple agencies. Even though federal authorities play an important role in the permitting process, the permitting authority lies with the cantonal and municipal agencies responsible for energy, zoning, the environment, and building. ${ }^{37}$

\section{Quantification of the Policy Risk Premium}

\subsection{Methodological Approach}

The following section focuses on the quantification of the risk premium, which was done by comparing the profitability and the LCOE of a reference project (risk-free scenario) with several risk-adjusted scenarios, when the project witnessed regulatory challenges. The calculations were based on the discounted cash flow model, expressing project profitability in terms of the Net Present Value (NPV) and Internal Rate of Return (IRR), which are standard project evaluation methods in finance. ${ }^{38}$ For the calculation of project cash flows, the authors use annual Free Cash Flow to Firm (FCFF) values.

The LCOE calculations were based on an established method of accounting for project expenses and predicted electricity production at certain periods of time. LCOE was calculated with the following formula ${ }^{39}$ :

\footnotetext{
${ }^{35}$ Deloitte (2015).

${ }^{36}$ Swiss Federal Office of Energy (2019).

${ }^{37}$ Federal Office for Spatial Development (2017).

${ }^{38}$ Brealey et al. (2012).

${ }^{39}$ Adapted from Kost et al. (2018).
} 





Table 1 Reference case assumptions

\begin{tabular}{|c|c|}
\hline Input Parameters & Value \\
\hline \multicolumn{2}{|l|}{ Technical parameters } \\
\hline Number of turbines & 9 \\
\hline Nameplate capacity per turbine (MW) & 3 \\
\hline Capacity factor $(\%)$ & $20.9 \%$ \\
\hline Decrease in turbine power output (\%/year) & $1.6 \%$ \\
\hline Planning stage (years) & 7 \\
\hline Construction stage (years) & 1 \\
\hline Operating stage (years) & 20 \\
\hline \multicolumn{2}{|l|}{ Financial parameters } \\
\hline WACC & $3.97 \%$ \\
\hline Depreciation, years & 20 \\
\hline Corporate tax rate $(\%)$ & $17.81 \%$ \\
\hline Inflation rate $(\%)$ & $0 \%$ \\
\hline \multicolumn{2}{|l|}{ Building and $O \& M$} \\
\hline Construction cost (CHF/MW) & $2,200,000$ \\
\hline Interconnection cost (CHF) & 660,000 \\
\hline Operations \& maintenance (CHF/year) & 594,000 \\
\hline Increase of O\&M cost (\%/year) & $1 \%$ \\
\hline Ecological compensation measures (CHF) & 1500,000 \\
\hline Planning expenses (CHF/MW) & 130,000 \\
\hline \multicolumn{2}{|l|}{ Revenues } \\
\hline KEV remuneration in years $1-5, \mathrm{ct} / \mathrm{kWh}$ & 21.5 \\
\hline KEV remuneration in years $6-20, \mathrm{ct} / \mathrm{kWh}$ & 13.5 \\
\hline
\end{tabular}

$$
L C O E=\frac{\sum_{t=0}^{n} \frac{A_{t}}{(1+W A C C)^{t}}}{\sum_{t=0}^{n} \frac{M_{t, e l}}{(1+W A C C)^{t}}}
$$

- LCOE is levelized cost of electricity in $\mathrm{ct} / \mathrm{kWh}$;

- $\mathrm{A}_{\mathrm{t}}$ are all project expenses in cent $(0.01 \mathrm{CHF})$ in year $t$, including permitting expenses in the pre-construction stage, construction expenses, ecological compensation, and operations and maintenance (O\&M) expenses once the project is built;

- $\mathrm{M}_{\mathrm{t}}$ is produced electricity in $\mathrm{kWh}$ in year $t$;

- WACC is the discount factor;

- $\mathrm{n}$ is the project lifetime, including pre-construction stage.

It should be noted that our calculations of LCOE do not take into account taxes, so caution is advised in comparing LCOE results with the level of feed-in tariffs.

The reference case assumptions were selected to describe a financially attractive wind energy project with realistic features, which have been cross-checked with project developers during the interviews (Table 1). The reference case presents a 
planned wind park consisting of 9 wind turbines, with a capacity of $3 \mathrm{MW}$ each (27 MW in total). The capacity factor, which is a measure of annual electricity generation per MW installed, is $20.9 \%$, based on the average production values of wind energy projects in Switzerland in $2015 .{ }^{40}$ The turbines' efficiency decreases at a rate of $1.6 \%$ per year. ${ }^{41}$ The project developer expects the planning to take 7 years, construction to be completed in 1 year, and the turbines to generate electricity for 20 years. The project developer discounts her annual cash flows at the weighted average cost of capital (WACC) of $3.97 \% .^{42}$ The inflation rate is set at zero for simplicity. The capital expenditure is fully depreciated in 20 years. The corporate tax rate is $17.81 \%$, which is an average corporate Swiss tax rate. ${ }^{43}$ The model assumes 1-year intervals for cash flows, which occur at the end of each year.

The construction cost of the reference project is 59.4 million CHF (2.2 million $\mathrm{CHF} / \mathrm{MW}$ ) and it costs $660 \mathrm{kCHF}$ to connect the project to the power grid. After the construction, there is an annual expense of $594 \mathrm{kCHF}$ ( $1 \%$ of construction costs) for operations and maintenance $(\mathrm{O} \& \mathrm{M})$, which increases at a rate of $1 \%$ per year. The project developer expects to receive a feed-in tariff of $21.5 \mathrm{ct} / \mathrm{kWh}$ for the first 5 years of operation, followed by a lower KEV rate of $13.5 \mathrm{ct} / \mathrm{kWh}$ for the remaining 15 years. ${ }^{44}$ During the interviews, the project developers reported production costs ranging from 10 to $20.5 \mathrm{ct} / \mathrm{kWh}$.

Ecological compensation measures are carried out in the year of construction only if the project is realized, and they represent the NPV of all expenses on ecological compensation over the project's lifetime. They are assumed to cost 1.5 million CHF, which is due to the high number of planned turbines and increasingly stringent ecological requirements. After 20 years of power production, the developer expects to sell the turbines in the second-hand market, which should cover decommissioning costs; so the decommissioning is assumed to be cost-neutral. Note that project expenses in the reference case are rather conservative, tending to underestimate the project's risks rather than overestimate them.

In the beginning of the project, the developer earmarks a planning budget of 130,000 CHF per MW of planned capacity (3.5 million CHF), corresponding to about $6 \%$ of construction cost. For the reference case, project planning and ecological compensation expenses were informed by the values summarized from the interviews (Table 2). This represents a rather conservative assumption, given that the international literature reports planning budgets reaching $10 \%$ of the construction cost. $^{45}$ The planning expenses include wind measurements, environmental studies

\footnotetext{
${ }^{40}$ Wind Data (2017).

${ }^{41}$ Staffell and Green (2014).

${ }^{42}$ Swiss Federal Office of Energy (2016c).

${ }^{43}$ KPMG (2016).

${ }^{44}$ For reasons of simplicity, we assumed the standard feed-in tariffs for wind energy in years 6 to 20 rather than taking into account the exceptions specified in Appendix 1.3, section 3.2, of the Energy Ordinance (Energieverordnung, SR 730.01); Swiss Federal Office of Energy (2016b).

${ }^{45}$ Krohn et al. (2009); Blanco (2009).
} 
Table 2 Estimation of average expenses of wind project planning

\begin{tabular}{l|l|r|r|c}
\hline Project planning expenses (kCHF) & Mean & Min & Max & SD \\
\hline Ecological compensation measures & 844 & 100 & 1700 & 536 \\
\hline EIA pre-study and main studies & 417 & 100 & 700 & 164 \\
\hline Coordination with stakeholders and PR & 550 & 200 & 1100 & 288 \\
\hline General technical planning & 398 & 100 & 1500 & 480 \\
\hline Wind speed measurements & 243 & 80 & 530 & 152 \\
\hline Planning of grid interconnection & 109 & 50 & 200 & 58 \\
\hline Federal permits and interests & 20.5 & 9 & 35 & 7.7 \\
\hline HR expenses, accounting, controlling, legal advice & 500 & & & \\
\hline Municipal court cases (1/2 year delay) & $30-50 /$ case & & & \\
\hline Cantonal court cases (1 year delay) & $30-50 /$ case & & & \\
\hline Federal court case (2 years delay) & $50-100 /$ case & & & \\
\hline Insurances, land rent, leases & 50 & & & \\
\hline
\end{tabular}

and mitigation measures, salaries for lawyers, engineers, financial managers, as well as PR and stakeholder management expenses. The minimum and maximum values vary considerably depending on the interviewee, which can be explained by differences in project accounting, varying project complexity, and project experiences. Still, Table 2 presents a useful illustration of project planning expenses.

One of the most significant cost categories is connected to EIA and ecological mitigation measures, often accounting for half of the planning budget. EIAs take 1.5 to 6 years to perform and range in total cost from $100 \mathrm{kCHF}$ for simpler studies to $700 \mathrm{kCHF}$ for longer and more complex estimations. Similarly, all except for one interviewee reported ecological compensation measures in excess of half a million Swiss francs. Coordination with stakeholders was a significant cost category for some project developers, leading to spending of up to 1.1 million CHF over the project lifetime. In contrast, other developers planned several hundred thousand Swiss francs on such activities per year during the planning stage, depending on the type of activities carried out (organization of site visits and informational meetings with or without catering; noise simulations; preparation of dossiers, website, posters, and flyers; communication campaigns; support of local community activities).

The technical dimension of the project requires planning by experienced engineers, which can be done in-house or outsourced to an engineering company, costing on average about $400 \mathrm{kCHF}$ (might include geotechnical study, road access survey, etc.) and taking 4-5 months to complete. Similarly, wind measurements depend on project complexity and can be completed in several stages, costing from under $100 \mathrm{kCHF}$ to more than half a million CHF. Obtaining the permit for wind measurements can take several months for approval and can be subject to objections. Planning for interconnection might cost about $100 \mathrm{kCHF}$.

One of the cost categories that are most difficult to predict is the HR expense for project management and expenses for legal advice, as these directly increase with project delays, the number of objections, the number of subsequent court cases, and 
Table 3 Summary of scenarios

\begin{tabular}{|c|c|c|}
\hline Scenario & Description & Details \\
\hline I & Delays & 3- or 10-year delay in permitting \\
\hline II & $\begin{array}{l}\text { Lower capacity } \\
\text { factor }\end{array}$ & $\begin{array}{l}\text { Reduction of capacity factor to } 19.9 \% \text { or } 17.9 \% \text { due to switching } \\
\text { off of turbines }\end{array}$ \\
\hline III & $\begin{array}{l}\text { Lower installed } \\
\text { capacity }\end{array}$ & 7 or 5 turbines are permitted instead of 9 \\
\hline IV & $\begin{array}{l}\text { Planning costs } \\
\text { increase }\end{array}$ & Increase of planning costs to $200 \mathrm{kCHF} / \mathrm{MW}$ or $400 \mathrm{kCHF} / \mathrm{MW}$ \\
\hline $\mathrm{V}$ & $\begin{array}{l}\text { Combination } \\
\text { scenario }\end{array}$ & $\begin{array}{l}\text { Low risk: } 3 \text { years of delay, capacity factor is } 19.9 \%, 7 \text { turbines } \\
\text { permitted, planning budget is } 200 \mathrm{kCHF} / \mathrm{MW} \\
\text { High risk: } 10 \text { years of delay in permitting, capacity factor is } 17.9 \% \text {, } \\
5 \text { turbines permitted, planning budget is } 400 \mathrm{kCHF} / \mathrm{MW}\end{array}$ \\
\hline VI & KEV phased out & Electricity sold at market price of $4 \mathrm{ct} / \mathrm{kWh}$ or $8 \mathrm{ct} / \mathrm{kWh}$ \\
\hline VII & $\begin{array}{l}\text { KEV payments } \\
\text { delayed }\end{array}$ & $\begin{array}{l}\text { Payments delayed by } 1 \text { or } 2 \text { years, electricity sold at market price } \\
\text { of } 4 \mathrm{ct} / \mathrm{kWh}\end{array}$ \\
\hline VIII & $\begin{array}{l}\text { KEV payments } \\
\text { reduced }\end{array}$ & KEV reduced by $10 \%$ or $20 \%$ in all years \\
\hline
\end{tabular}

court instances involved. We made a conservative estimation of $500 \mathrm{kCHF}$ over the planning period but also provide mean values for legal expenses per court case, which would be added to the planning budget as they arise. Finally, we include the cost of insurances, land rent and leases, estimated at $50 \mathrm{kCHF}$.

In order to evaluate marginal impacts of different administrative hurdles, we compute the NPV, IRR, and LCOE in the reference case and different scenarios. Each scenario investigates two levels of risk: low risk and high risk. The overall aim of the scenarios is to determine which factors have the highest impact on project profitability and hence represent the most severe policy risk.

Scenario I investigates changes in profitability and LCOE as a result of a 3-year (low risk) and 10-year (high risk) delay in project development in the pre-construction stage. The planning budget increases by $100 \mathrm{k}$ CHF for every year of delay, which accounts for additional project management hours, legal advice costs and coordination efforts.

Scenario II illustrates the detrimental effect of policy-induced reductions in the project's capacity factor. Full load hours are usually predicted based on wind measurements in the pre-construction stage. Yet, decreased hours of operation can be a measure of ecological compensation, as the turbines might have to be switched off to protect migratory birds or vulnerable bat species. The turbines in the reference case operate with 1831 full load hours a year (20.9\% capacity factor), while Scenario II evaluates the changes in LCOE if the turbines work with a capacity factor of $19.9 \%$ (low risk) and $17.9 \%$ (high risk). A similar negative effect is expected in Scenario III, where there are fewer turbines (5 in the low-risk case or 7 in the highrisk case) permitted than originally planned. In Scenario IV, we investigate cost overruns that increase the planning budgets to $200 \mathrm{kCHF}$ (low risk) and $400 \mathrm{kCHF}$ (high risk) per MW of installed capacity (Table 3 ). 
Scenario $\mathbf{V}$ combines multiple administrative hurdles and is, in many ways, mirroring the reality of several Swiss wind projects. First, low project risks from Scenarios I-IV are combined: planning takes 10 years, the planning expenses increase to $200 \mathrm{kCHF} / \mathrm{MW}$, only 7 out of 9 turbines are permitted, and the capacity factor is reduced to $19.9 \%$. In the high-risk combination scenario, we investigate a 5-turbine project with a pre-construction stage of 17 years and a planning budget of $400 \mathrm{kCHF} / \mathrm{MW}$, with a capacity factor of $17.9 \%$.

Finally, we investigated the impacts of the level and duration of KEV payments on the project's profitability (represented by IRR and NPV). Since LCOE does not account for project revenues, it is not calculated here. We investigated whether wind energy projects will be developed in Switzerland without KEV (Scenario VI) and what levels of electricity market prices are necessary to make wind projects financially attractive. For modeling simplicity, we disregarded electricity price volatility and assumed a constant price of $4 \mathrm{ct} / \mathrm{kWh}$, which was the average spot price for Swiss base load electricity in the day-ahead market between July 2015 and July $2016^{46}$ and which is also within the range of the Swiss Federal Office of Energy's electricity price projections. ${ }^{47}$ The low-risk Scenario VI assumes the market price to be $8 \mathrm{ct} / \mathrm{kWh} .{ }^{48}$ Additionally, we looked at project profitability if KEV payments are delayed by 1 or 2 years and the electricity is sold at the market price of $4 \mathrm{ct} / \mathrm{kWh}$ (Scenario VII). Finally, we calculated profitability changes due to an overall reduction in KEV support (by 10\% or 20\%) (Scenario VIII).

\subsection{Results: The Price of Policy Risk}

This section provides an indication of the magnitude of the policy risk premium faced by project developers due to challenges in the pre-construction stage. We compare LCOE in the risk-free scenario to the eight scenarios with policy risks introduced in the previous section. The LCOE of the reference case is $12.57 \mathrm{ct} / \mathrm{kWh}$. Under the base case assumptions, the project is a reasonably attractive investment with an IRR of 6.68\%, an NPV of 10.3 million CHF and a payback time of 10 years after construction. The following scenarios illustrate marginal impacts of policy risks on the reference case.

Scenario I A 3-year delay increases LCOE by $0.16 \mathrm{ct} / \mathrm{kWh}$ and results in 1.76 million in losses in NPV (Fig. 3). A 10-year delay in project development creates 4.42 million in losses in NPV for the investor, increasing LCOE by $0.37 \mathrm{ct} / \mathrm{kWh}$.

\footnotetext{
${ }^{46}$ Bloomberg (2016).

${ }^{47}$ Swiss Federal Office of Energy (2016c).

${ }^{48}$ Because of price volatility in the electricity market, it is challenging to predict a wind project's revenues over its lifetime of at least two decades. This assumption is representative of the electricity price level when KEV was initially introduced. In late 2019 , wholesale prices were $4 \mathrm{ct} / \mathrm{kWh}$ (www. epexspot.com), corresponding to the high-risk scenario.
} 

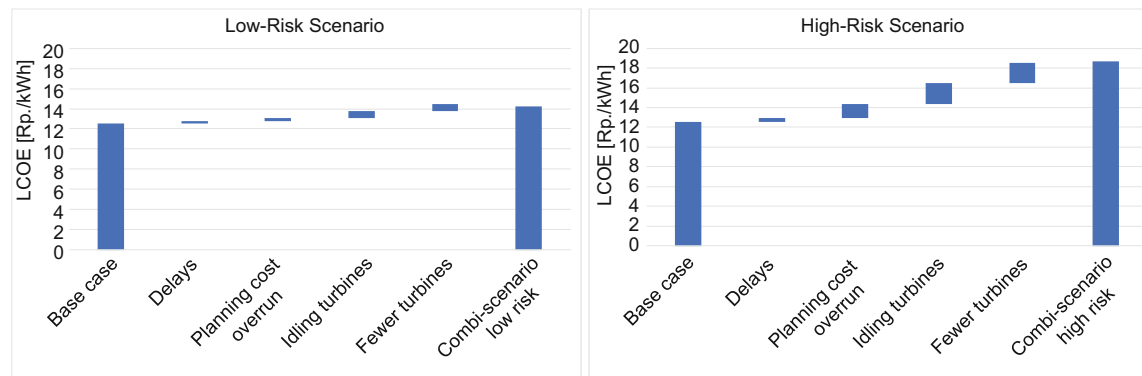

Fig. 3 Risk-adjusted LCOE in Scenarios I-V (high vs. low risk)

Note that these numbers account for only $100 \mathrm{kCHF}$ in additional expenses per year of delay, thus increasing the planning budget by $300 \mathrm{kCHF}$ and one million $\mathrm{CHF}$ altogether. Despite these rather small changes in the planning budget $(0.5 \%$ and $1.7 \%$ of construction cost), the estimated profitability losses and LCOE increases are considerable. This observation illustrates an important lesson learned: project delays have a much larger impact on project profitability than is obvious from the direct additional expenses.

In addition to direct costs, delays in project development are connected to indirect costs, such as the opportunity cost of capital. During the years of permitting, the capital earmarked for the project is not productive; yet, it could have been invested at a profit elsewhere. A simple calculation of the opportunity cost shows that if the project developers in the reference case invested their planning budget of 3.5 million $\mathrm{CHF}$ into a financial vehicle with an annual yield of $3 \%$, they would have obtained $105 \mathrm{kCHF}$ in revenue per year. In 15 years, the project developers would have earned nearly two million CHF on their initial investment. In case of a wind project, the developers do not see any return on their investment for the duration of the permitting stage. Thus, the idling capital should be of the same level of concern as idling wind turbines.

Moreover, administrative delays make the project developer forego profits from electricity production, which also could have been reinvested. Depending on the assumptions, foregone profits from electricity generation also run into hundreds of thousands of francs, funds that cannot be reinvested if the project gets delayed. Even though opportunity costs of capital and foregone profits do not enter the financial accounting of the project developer, they should not be neglected, since they reduce the overall attractiveness of the project.

Scenario II Major profit-reducing events can occur if not all planned turbines are permitted or the turbines remain idle due to restrictions. Switching off wind turbines can be a measure of environmental conservation. The reduction in capacity factor by one percentage point to $19.9 \%$, brings about an average loss in NPV of 2.8 million $\mathrm{CHF}$ and increases LCOE by $0.63 \mathrm{ct} / \mathrm{kWh}$. If the capacity factor decreases to $17.9 \%$, the NPV losses amount to 8.4 million CHF compared to the reference case. If this high risk is present, the LCOE increases by $2.11 \mathrm{ct} / \mathrm{kWh}$. 


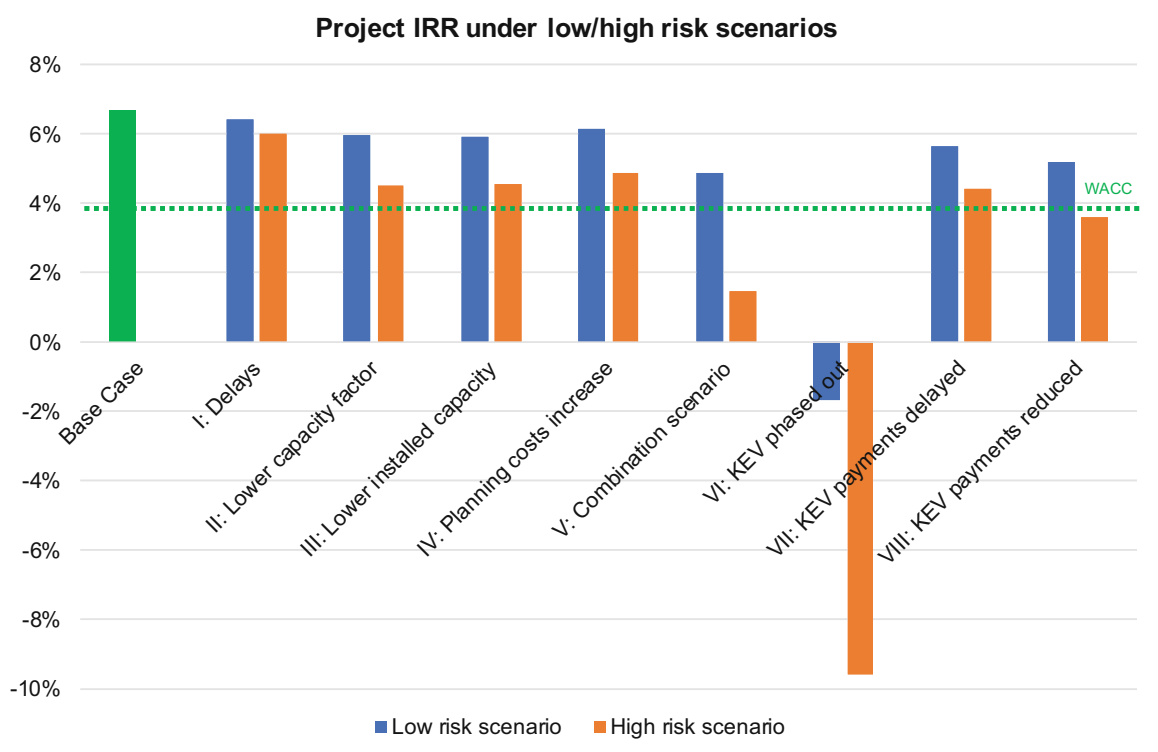

Fig. 4 Impact of policy risk on project's internal rate of return (IRR)

Scenario III A significant decrease in profitability is experienced if multiple turbines are not permitted. If only 7 of the 9 originally planned turbines can be built, LCOE increases by $0.73 \mathrm{ct} / \mathrm{kWh}$. If only 5 turbines are permitted, LCOE climbs by $2.04 \mathrm{ct} / \mathrm{kWh}$. Thus, reducing the capacity factor to $17.9 \%$ due to the switching off of turbines has roughly the same impact on LCOE as having 4 of the planned 9 turbines not permitted. The reference project needs at least $14 \mathrm{MW}$ of production capacity to break even. If the project faces additional costs and delays, it requires larger capacities to counterbalance the permitting expenses. This illustrates the sensitivity of wind projects to the number of hours the rotor is allowed to turn and the number of turbines in the park.

Scenario IV The planning budget is likely to increase when the project is experiencing delays. If the planning costs increase to $200 \mathrm{k}$ per $\mathrm{MW}$ of installed capacity, the project developer will not only have to invest 1.89 million CHF more into the project in the pre-construction stage, but the LCOE also increases by $0.38 \mathrm{ct} /$ $\mathrm{kWh}$. In a high-risk case, the planning costs would reach $400 \mathrm{kCHF} / \mathrm{MW}$, which would increase LCOE by $1.44 \mathrm{ct} / \mathrm{kWh}$, making the project only marginally attractive with an IRR of $4.88 \%$ (Fig. 4). From the interviews we have learned that some project developers would abandon a project if the planning cost reaches half a million CHF per MW. The planning costs for abandoned projects need to be implicitly won back by successful projects, putting an upward pressure on the required level of KEV payments.

Scenario V So far, the calculations estimated the marginal impacts of policy risks on project profitability and LCOE levels. The low-risk combination scenario 
illustrates a case that is fairly representative of many Swiss wind projects: 3 years of delays, a lower than planned capacity factor of 19.9\%, 7 turbines permitted, the planning budget amounting to $200 \mathrm{kCHF} / \mathrm{MW}$. The IRR of the combination scenario is $4.87 \%$, which is still higher than WACC but does not represent a high-yield investment. At the same time, LCOE would rise to $14.22 \mathrm{ct} / \mathrm{kWh}$, which is higher than the nominal KEV remuneration in years 6-20. This implies that the profitability of the project would be substantially lower than initially projected.

If we combine the high-risk scenarios (10 years delay, reduction in capacity factor to $17.9 \%, 5$ turbines permitted, increase of planning costs to $400 \mathrm{kCHF} / \mathrm{MW}$ ), LCOE rises to the unsustainable level of $18.67 \mathrm{ct} / \mathrm{kWh}$. The cumulative policy risks would reduce the IRR below WACC, yielding a negative NPV, which suggests that an economically rational developer would abandon the project, as it will not be profitable. The combination scenario illustrates how multiple policy risks that are present in reality can have a significant negative impact on a project's financial performance. Unless minimized, these policy risks can hamper the prospects of development of wind energy projects.

Figure 3 presents the effects of the policy risks illustrated in Scenarios I-V on the risk-adjusted LCOE of wind energy in Switzerland. In order to make a positive investment decision, a project developer would compare LCOE with achievable revenues, i.e., remuneration from KEV or electricity sales.

Scenarios VI-VIII The highest risks to a project's financial viability are related to the unavailability, reduction, or delays of KEV payments. In line with the information received during the interviews, we find that no wind project can be developed without KEV in the current market conditions. If KEV payments are not available for 1 year and the electricity price is $40 \mathrm{CHF} / \mathrm{MWh}$, the profitability of the whole project drops by 1.03 percentage points, which would cost the project developer 3.5 million CHF. Delaying KEV for 2 years in the initial years of operation is equivalent to not allowing 4 out of 9 wind turbines to be built in NPV terms. A relatively high market price for electricity is required for the project to be financially viable in the absence of a feed-in tariff: with the assumed WACC (3.97\%), the wind project's NPV was positive when the average market price of electricity reached $13.5 \mathrm{ct} / \mathrm{kWh}$ for all years of operation. A minimum KEV support of $16.0 \mathrm{ct} / \mathrm{kWh}$ is required for all years of operation to maintain the profitability of $6 \%$. If the level of KEV support is reduced by $10 \%$, the project's NPV decreases by more than 5.84 million CHF (1.51 percentage point loss in terms of IRR). More significant reductions of KEV, say by $20 \%$, are likely to deter investment, as the net present value of cash flows turns negative and IRR (3.08\%) is below WACC. Note that the relationship between the reduction of KEV and losses in profitability is not one to one: if KEV is reduced by $10 \%$, the profitability decreases by more than $22 \%$.

Figure 4 summarizes the discussions in this section, illustrating how the initial project IRR of $6.68 \%$ would be affected by the policy risks discussed in Scenarios I to VIII. The dotted green line represents the assumed weighted average cost of capital of $3.97 \%$. Policy risks can significantly reduce the expected rate of return, 
and let it fall below WACC and even to negative absolute values in some cases, suggesting that the project would turn unprofitable if the assumptions in some of the high-risk scenarios materialize.

\section{Conclusion and Policy Implications}

The profitability of a wind park is determined by an interplay of project risks and returns. Most risks in wind energy development occur in the permitting stage, while returns are only realized after the project is built (see Fig. 5). In order to incentivize investment in wind power, policymakers can (1) reduce the risks in the planning stage, (2) compensate investors for taking those risks through higher returns, or (3) shorten the planning stage to reduce uncertainty about both risks and returns. Many Swiss wind energy projects currently have a high-risk/high-return profile. Project developers are facing significant risk in the planning stage, and they receive attractive returns (in the form of the KEV) in those (few) cases where the project can actually be built. For projects not completed before the expiration of feed-in tariffs at the end of 2022, financing crucially depends on parliamentary decisions about any follow-up scheme or on their ability to secure a long-term power purchase agreement (PPA) at sufficiently favorable conditions. From a societal point of view, shifting

\section{Wind project development process}
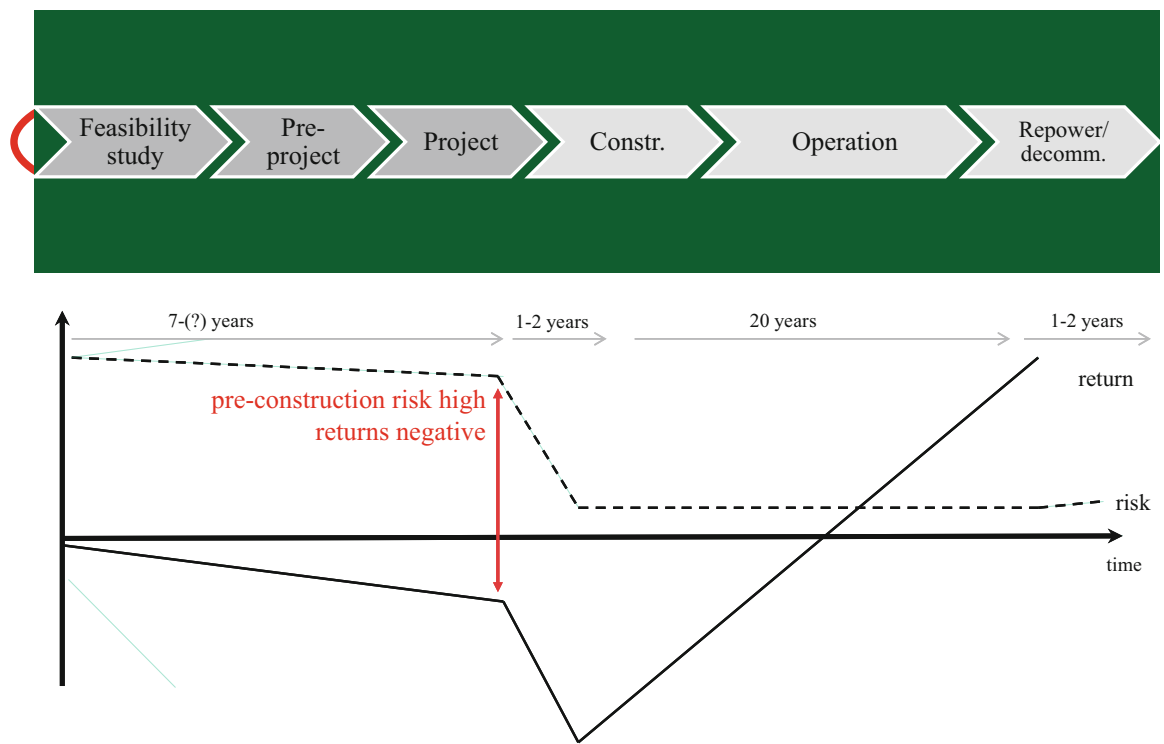

Fig. 5 Risk-return profile in wind energy project development 
more projects towards the low-risk/low-return end of the spectrum would be preferable.

Above all, this implies decreasing project risks in the pre-construction stage. Possible measures include simplifying and streamlining permitting procedures, creating regulatory clarity, and expediting court cases. An important consideration is to implement such measures in a way that maintains social acceptance of wind energy by relevant stakeholders. Successful wind projects are characterized by an alignment of interests between investors and local communities, which can for example be facilitated by enabling financial participation of the local population in the project ${ }^{49}$ or public support for the planning of community wind projects. ${ }^{50}$ An approach that has had positive effects on social acceptance in some regions of Switzerland was to gain experience with one or a few turbines before planning an extended project. This allows concerns of the local population, e.g., about noise, to be contrasted with first-hand evidence and can, through word-of-mouth, facilitate further development of wind energy also in neighboring regions.

While a large number of measures is available to improve administrative procedures and reduce the policy risk premium, coordinating the variety of stakeholders in a federal democracy is not an easy task. The upside of successfully engaging in this task is to secure a clean, affordable domestic supply of electricity - which is ultimately what a majority of the population voted for in the 2017 referendum about the Energy Strategy 2050.

\section{References}

Battaglini A, Komendantova N, Brtnik P, Patt A (2012) Perception of barriers for expansion of electricity grids in the European Union. Energy Policy 47:254-259

Bergek A, Mignon I, Sundberg G (2013) Who invests in renewable electricity production? Empirical evidence and suggestions for further research. Energy Policy 56:568-581

Blanco M (2009) The economics of wind energy. Renew Sust Energ Rev 13(6-7):1372-1382

Blondiau Y, Reuter E (2019) Why is the grass greener on the other side? Decision modes and location choice by wind energy investors. J Bus Res 102:44-55

Bloomberg (2016) Bloomberg ticker for Swiss base load day-ahead power: LSWBHRBS Index

Brealey RA, Myers SC, Allen F, Mohanty P (2012) Principles of corporate finance. Tata McGrawHill Education

Bürer MJ, Wüstenhagen R (2008) Cleantech venture investors and energy policy risk: an exploratory analysis of regulatory risk management strategies. In: Wüstenhagen R, Hamschmidt J, Sharma S, Starik M (eds) Sustainable innovation and entrepreneurship. Edward Elgar Publishing, pp 290-309

Burkhardt J, Wiser R, Darghouth N, Dong CG, Huneycutt J (2015) Exploring the impact of permitting and local regulatory processes on residential solar prices in the United States. Energy Policy 78:102-112

\footnotetext{
${ }^{49}$ Tabi and Wüstenhagen (2015).

${ }^{50}$ Scottish Government (2013).
} 
Ceña A, Iuga D, Simonot E, Fichaux N, Wokke S, Strom S (2010) Wind barriers: administrative and grid access barriers to wind power. European Wind Energy Association (EWEA), Brussels

De Jager D, Rathmann M (2008) Policy instrument design to reduce financing costs in renewable energy technology projects. Project report for the IEA Implementing Agreement on Renewable Energy Technology Deployment (RETD). Ecofys, Utrecht

Deloitte (2015) Establishing the investment case: Wind Power. August 2015. Available at https:// www.scribd.com/document/294176431/Deloitte-Establishing-the-Investment-Case

Dong C, Wiser R (2013) The impact of city-level permitting processes on residential photovoltaic installation prices and development times: an empirical analysis of solar systems in California Cities. Energy Policy 63:531-542

Ebers A, Wüstenhagen R (2016) 6th consumer barometer renewable energy in collaboration with Raiffeisen. University of St. Gallen. Available at www.iwoe.unisg.ch/kundenbarometer

Ebers Broughel A, Stauch A, Schmid B, Vuichard P (2019) Consumer (co-)ownership in renewables in Switzerland. In: Lowitzsch J (ed) Energy transition: financing consumer coownership in renewables. Palgrave McMillan, pp 451-476

Ebers Broughel A, Hampl N (2018) Community financing of renewable energy projects in Austria and Switzerland: profiles of potential investors. Energy Policy 123:722-736

Federal Chancellery (2017) Vorlage Nr. 612, Vorläufige amtliche Endergebnisse, Energiegesetz (EnG) vom 30.09.2016. Available at https://www.admin.ch

Federal Council (2016) Zugvögel und Windenergie: Weltweit erste kombinierte Studie zu Schlagopfern und Vogelzugintensität. Press Release. Available at https://www.admin.ch

Geissmann M (ed) (2015) Social acceptance of wind energy projects: winning hearts and minds. State-of-the-art Report. Country Report for Switzerland. IEA Wind Task 28. Available at http:// www.socialacceptance.ch

Guy-Ecabert C, Meyer F (2016) Leitfaden zur Optimierung der Praxis bei der Planung von Windparks. 31 March 2016. Swiss Federal Office of Energy, Bern

Kost C, Mayer J, Thomsen J, Hatmann N, Senkpiel C, Philipps S et al (2018) Levelized cost of electricity - renewable energy technologies. March 2018, Fraunhofer Institute for Solar Energy Systems ISE, Freiburg

KPMG (2016) Clarity on Swiss Taxes. Available at https://home.kpmg/ch/en/home.html

Krohn S, Morthorst P-E, Awerbuch S (eds) (2009) The economics of wind energy. Report of European Wind Energy Association. Brussels. Available at: http://www.ewea.org

Lüthi S, Prässler T (2011) Analyzing policy support instruments and regulatory risk factors for wind energy deployment—a developers' perspective. Energy Policy 39(9):4876-4892

Lüthi S, Wüstenhagen R (2012) The price of policy risk - empirical insights from choice experiments with European photovoltaic project developers. Energy Econ 34(4):1001-1011

Noothout P, De Jager D, Tesniere L, van Rooijen S, Karypidis N, Brückmann R et al (2016) The impact of risks in renewable energy investments and the role of smart policies. Diacore report. Fraunhofer ISE, Ecofys, eclareon, EPU-NTUA, LEI, TU Wien. February 2016. Available at http://publica.fraunhofer.de/starweb/pub09/index.htm

Perret L (2019) Recherche sur l'acceptation et énergie éolienne. Presentation at NRP70 Event on Social Acceptance. Bern, 26 June 2019. Available at https://api.nfp-energie.ch/api/de/content/ file/35e733e7e019d194810f4c9221ec9727

Plüss K (2017) Interessensabwägung beim Bau von Wasser- und Windenergieanlagen. Schriften zum Energierecht, Band 4.Dike Verlag, Zurich/St. Gallen

Pronovo (2019a) Pronovo-Cockpit. 3rd quarter 2019. Status as of 1 October 2019. Available at https://pronovo.ch/de/services/berichte/

Pronovo (2019b) Facts EVS. Available at https://pronovo.ch

Rinscheid A, Udris L (2021) Referendum campaigns in Swiss energy policy. In: Hettich P, Kachi A (eds) Swiss energy governance. Springer, New York

Rinscheid A, Wüstenhagen R (2018) Divesting, fast and slow: affective and cognitive drivers of fading voter support for a nuclear phase-out. Ecol Econ 152:51-61 
Scottish Government (2013) Community and Renewable Energy Scheme (CARES). Available at http://www.gov.scot

Staffell I, Green R (2014) How does wind farm performance decline with age? Renew Energy 66:775-786

Suisse Eole (2016) Windjahr 2015: Deutlich höhere Windstromproduktion, aber keine neuen Anlagen. Press release, 19 February 2016. Available at https://www.suisse-eole.ch

Suisse Eole (2019) Windenergie in der Schweiz in Zahlen. Fact Sheet, 22 February 2019. Available at https://www.suisse-eole.ch

Swiss Federal Office for Spatial Development (2017) Concept for wind energy for Switzerland. Available at https://www.are.admin.ch

Swiss Federal Office of Energy (2016a) Energy Strategy 2050. Available at http://www.bfe. admin.ch

Swiss Federal Office of Energy (2016b) Feed-in remuneration at cost. Available at http://www.bfe. admin.ch

Swiss Federal Office of Energy (2016c) Überprüfung der Gestehungskosten und der Vergütungssätze von KEV-Anlagen. May 2016. Available at https://www.admin.ch

Swiss Federal Office of Energy (2019) Guichet Unique Windenergie. Available at https://www.bfe. admin.ch

Tabi A, Wüstenhagen R (2015) Befragung der Anwohner von möglichen Windparks in der Ostschweiz. University of St. Gallen. November 2015

Tamedia (2017) Die meisten finden ein Windrad als Nachbar okay. Follow-up survey on the popular vote on the Energy Act, 20 May 2017. Available at http://www.20min.ch

Twele J, Liersch J (2011) Planning, operation and economics of wind farm projects. In: Gasch R, Twele J (eds) Wind power plants: fundamentals, design, construction and operation. Springer, Berlin, pp 480-519

Wind Data (2017) Standorte von Windkraftanlagen in Betrieb. Produktion 2015. Available at http:// wind-data.ch

Wolsink M (2007) Wind power implementation: the nature of public attitudes: equity and fairness instead of 'backyard motives'. Renew Sust Energ Rev 11(6):1188-1207

Wüstenhagen R, Wolsink M, Bürer MJ (2007) Social acceptance of renewable energy innovation: an introduction to the concept. Energy Policy 35:2683-2691

Wüstenhagen R, Blondiau Y, Ebers A, Salm S (2017) Lowering the financing cost of Swiss renewable energy infrastructure: Reducing the policy risk premium and attracting new investor types. Report SI/501293-01. Swiss Federal Office of Energy. Available at https://www.aramis. admin.ch

Anna Broughel is a senior energy economist at Tetra Tech and an adjunct professor at Johns Hopkins University and at the University of Maryland College Park. Her most recent research reviewed over 120 international energy scenarios for 2040 and beyond, developing scenarios for post-COVID19 energy futures. Prior to joining Tetra Tech, she worked at the U.S. Department of Energy as a Science and Technology Fellow. During her post-doctoral training at the University of St. Gallen in Switzerland, she researched social acceptance of wind energy and other energy technologies. She holds a PhD in economics and policy from the State University of New York in association with Syracuse University, where she was a Fulbright scholar.

Rolf Wüstenhagen University of St. Gallen, Chair for Management of Renewable Energies, St. Gallen, Switzerland. 
Open Access This chapter is licensed under the terms of the Creative Commons Attribution 4.0 International License (http://creativecommons.org/licenses/by/4.0/), which permits use, sharing, adaptation, distribution and reproduction in any medium or format, as long as you give appropriate credit to the original author(s) and the source, provide a link to the Creative Commons license and indicate if changes were made.

The images or other third party material in this chapter are included in the chapter's Creative Commons license, unless indicated otherwise in a credit line to the material. If material is not included in the chapter's Creative Commons license and your intended use is not permitted by statutory regulation or exceeds the permitted use, you will need to obtain permission directly from the copyright holder. 